\title{
Lectin from Pisum fulvum Seeds as in vitro Anticancer and Apoptotic Gene Regulator
}

\author{
ABDELRAHMAN MOHAMED YASSIN ${ }^{1}$, NEHAL MOHAMED EL-DEEB ${ }^{1}$, FAHMY GAD ELSAID ${ }^{2,3,4}$, ALI ABDULLAH SHATI ${ }^{2,3}$, \\ GABRIELA CIOCA ${ }^{5 *}$, DELIA MIRELA TIT ${ }^{6}$, SIMONA BUNGAU ${ }^{6}$, AMORIN POPA6*, ELSAYED ELSAYED HAFEZ ${ }^{7}$ \\ 'Biopharmacetical product research Department, Genetic engineering and biotechnology research institute' City of Scientific \\ Research and Technology Applications, New Borg El-Arab City 21934, Alexandria, Egypt \\ ${ }^{2}$ Research Center for Advanced materials Science (RCAMS), King Khalid University, Abha 61413, Box 9004, Saudi Arabia. \\ ${ }^{3}$ Biology Department, Science College, King Khalid University, Abha 61321, Saudi Arabia \\ ${ }^{4}$ Zoology Department, Faculty of Science, Mansoura University, Mansoura 35516, Egypt \\ ${ }^{5}$ Lucian Blaga University of Sibiu, Faculty of Medicine,10 Victoriei Blvd., 550024, Sibiu, Romania \\ University of Oradea, Faculty of Medicine and Pharmacy, Oradea, 410028, Romania \\ 'Department of Plant protection and biomolecular diagnosis, ALCRI, City of Scientific Research and Technology Applications, \\ New Borg El-Arab City, 21934, Alexandria, Egypt
}

The lectins are non-immune origin carbohydrate-binding proteins. Plant's lectins are distributed in many species of medicinal plants, family Fabaceae. In this study the safety usage pattern of wild Pisum fulvum lectin was evaluated on different mammalian noncancerous cell types and the anticancer activity was examined on different cancer human cell lines: colorectal adenocarcinoma (Caco-2), hepatocellular carcinoma (HepG2), breast cancer cells (MCF7) and laryngeal carcinoma (Hep-2 cells). Moreover, both morphological and molecular evidence of apoptosis have been detected using both acridine orange/ethidium bromide (AO/EB) stain and RT-qPCR. The results revealed that IC50 of the wild lectin on the noncancerous cells ranged from 19.7 to $2.4 \mu \mathrm{g}$ rotein $/ \mathrm{mL}$. In addition, lectin was more potent against HepG2 cells than the other used cells, with inhibition percentages ranged from 68.45 to 90.98 and with cancer cell selectivity index ranged 3.5 to 28.14 . The treatment showed $67.6 \%$ inhibition of BrdU incorporation in the proliferated hepatocellular carcinoma cells. Furthermore, HepG2-lectin treated cells showed obvious nuclear condensation after $48 \mathrm{~h}$ of treatment with ability to down-regulate the expression of $B C L 2$ and $B A X$ and to up-regulate the expression of Ikab gene. The results obtained in this research work clearly indicated the Pisum fulvum lectin could be a promising potential anticancer agent.

Keywords: lectin, Pisum fulvum, Fabaceae, cancer cell lines, antioxidant, anticancer

Lectins were identified since the $19^{\text {th }}$ century, but their importance was acknowledged 200 years ago [1]. It is a non-immune origin carbohydrate-binding protein. These glycoproteins are mostly found in plants, vertebrates, and invertebrates [2], but they are extensively present in different parts of the plants: leaves, barks, seeds and others, depending on the plantspecies [3]. Lectins are substances that belong to a group of proteins or glycoproteins, other than antibiotics or enzymes. They have the ability to specifically recognize those cell surface molecules with at least two binding sites that lead to cellular agglutination. In the more recent studies, proteins having at least one non-catalytic domain that binds reversibly to a specific mono- or oligosaccharide appear as lectins [4]. Lectins were categorized based on their carbohydrate types: mannose binding [5], glucose binding [6-10], galactose binding [11], but a new classification system was postulated based on their origin (animal or plant) and structures [12]. Plant lectins were classified into 12 different groups, in accordance to their structural and evolutionary relationships when compared with legume lectins, jacalins, and amaranthins [13]. Phyto lectins have a significant contribution in cancer research and achievements, because they are implied in several processes of cell biology [14-17]. On the basis of their mechanism of action, the lectins extracted from plants can act in many ways: biological processes as lectin-based delivery systems in medicine, biomedical research as diagnostic, treatment of diseases, plant protection, etc. [18]. They are extensively involved in different biological cell processes as cell immune response, cell-cell and host-pathogen interaction, in addition to their positive effects on tumour growth and metastatic spread [19]. Moreover, they are able to modify the cell cycle by inducing both cell cycle seizure and caspase cascade; also, the genes induction plays the principal role in apoptotic cell death. It was reported that lectins have positive action on the interleukins, but downregulate telomerase activity [20]. Other studies concluded that lectins could have several applications as therapeutic agents (by binding these compounds to cancer cell membranes and/or their receptors, which finally control the tumour growth [21]), anticancer agents, and potential cancer marker. The effect of galactose-binding lectin is similar to the other extracted from seeds of peanut.

Majority of the known lectins have been extracted and isolated from plants belonging to family Leguminosae, or recently renamed as family Fabaceae [22], which includes the genus Pisum. This genus contains also: the cultivated species $P$. abyssinicum, which was domesticated independently of $P$. sativum $L$.; the wild species $P$. fulvum; a large complex of species, both wild ( $P$. sativum $L$. subsp. elatius) and cultivated, including the $P$. sativum species in a broad sense [23].

The aim of the present study was the partial purification of the lectin from the seeds of the wild medicinal plant Pisum fulvum and to examine its activity as anticancer agent, by studying the responses of three different cancer cell lines toward the lectins and their mode of action on the treated cell lines compared to the non-treated ones. 


\section{Experimental part}

Materials and methods

Mammalian cell line

As non-cancerous cell lines, human amnion cells (WISH), human primary dermal fibroblasts cells, African green monkey kidney cells (VERO), Syrian hamster kidney cells (BHK), and Madin-Darby canine kidneycells (MDCK) were used. As cancer cell lines were used: human colorectal adenocarcinoma cells (Caco-2), human hepatocellular carcinoma cells (HepG2), human larynx carcinoma cells (Hep-2 cells), and human breast cancer cells (MCF7). All used cell lines were cultured in either DMEM or RPM11640 media complemented with $200 \mu \mathrm{M}$ Iglutamine and $25 \mu \mathrm{M}$ HEPES buffer, N-[2-hydroxyethyl] piperazine-N-[2-ethanesulphonic acid] (all chemicals and media, Cambrex).

\section{Plant materials}

Plant seeds of wild medicinal plant Pisum Fulvum, family Leguminosae/ Fabaceae) were collected from naturally grow $n$ plants in gardens around Borg-El Arab city, Alexandria, Egypt in J une 2017. The plant was taxonomy identified by Professor Ibrahim Abd El-Rahim Mashaly, Botany Department, Faculty of Science, Mansoura University. A voucher specimen ( $P$. fulvum 2231) is deposited at the Herbarium of the Botany Department, Mansoura University.

\section{Extraction and isolation}

Extraction and purification of lectins from Pisum fulvum seeds was previously done according Al-Sohaimy et al. [21], with some modifications. Briefly, about $30 \mathrm{~g}$ of the plant seeds were ground and stirred in $0.15 \mathrm{M} \mathrm{NaCl}$ with ratio $1: 8$. After soaking with stirring overnight at $4^{\circ} \mathrm{C}$, the mixture was filtered through $80 \mathrm{~mm}$ mesh. The filtrate was centrifuged at $9000 \mathrm{rpm}$ for $30 \mathrm{~min}$ at $4^{\circ} \mathrm{C}$, and protein was precipitated by $50 \%$ ammonium sulphate solution overnight. Then, the protein precipitate was collected, and the total protein content was determined using bovine serum albumin as standard.

\section{Lectin cytotoxicity}

In order to determine the safe dose of the extracted lectin, fibroblast cells, MDCK and PHK cells were used as noncancerous cell model. The cytotoxicity assay was carried out according to Borenfreund and Puerner recommendation [24]. Briefly, cells suspension $\left(6 \times 10^{4}\right.$ cell $/ \mathrm{mL}$ ) was seeded in the flat bottom 96-well plates; $100 \mu \mathrm{L}$ of different plant extract concentrations was added. After 2 days of treatments, the cells were stained with 100 $\mu \mathrm{L}$ of neutral red stain $(100 \mu \mathrm{g} / \mathrm{mL})$ for $3 \mathrm{~h}$. Only the living cells are permeable to the neutral red and incorporated it into liposomes, providing a quantitative assay to the cytotoxic effects. The stain intensity was assayed at O.D. $540 \mathrm{~nm}$ using automated ELIZA microplate reader (reference filters $620 \mathrm{~nm}$ ).

Anticancer activities of the extracted lectin

The anti-cancer activities of the lectin on the human colorectal adenocarcinoma Caco-2, HepG2, MCF7 and Hep-2 cells were assessed using neutral red dye as previously mentioned in the above section. Proliferation was examined using neutral red staining depending on the evaluation of cell membrane integrity. After incubation, the stain intensity was assayed using automated ELIZA microplate reader at $540 \mathrm{~nm}$ (reference filters $620 \mathrm{~nm}$ ). The cellular changes upon the treatment were noticed under the inverted microscope.

Selectivity index (SI)

The degree of the selectivity of the treatment is expressed similar with the previous reports $[25,26]$ : $S I=L C_{50}$ of pure treatment in a normal cell line/ $L C_{50}$ of the same treatment in the cancer cell line, where $\mathrm{LC}_{50}$ represents the concentration required to kill $50 \%$ of the cell population.

\section{Proliferation assay}

According to the manufacturer's protocol of Cell Proliferation ELISA BrdU Kit (Roche Applied Science), cell proliferation in the response to the treatments was determined using the measurements of BrdU incorporated into the cellular DNA, during the cell proliferation.

Total antioxidants of the wild lectin

The total antioxidants were measured in the both cases: treated and non-treated cells. At the end of the incubation time, the cells were homogenized, and the total antioxidants were measured using Biodiagnostic kit, according to the manufacture instructions.

Apoptosis detection by acridine orange/ethidium bromide (A.O. / E.B.) stain

Cells undergoing apoptosis were detected by acridine orange and ethidium bromide [27]. At the end of the treatment, about $25 \mu \mathrm{L}$ of cell suspension $\left(0.5 \times 10^{6}\right.$ cells/ $\mathrm{mL}$ ) were incubated with $1 \mu$ l of A.O. / E.B. solution. Using a fluorescence microscope, $10 \mu \mathrm{L}$ of cell suspension was examined onto a microscopic slide. Acridine orange is a vital dye; it could stain both live and dead cells while, ethidium bromide will stain only cells that have lost membrane integrity.

\begin{tabular}{|c|c|}
\hline Primer's name & SEQUENCE FROM 5'-3' \\
\hline B-Actin & $\begin{array}{c}\text { Forward: 5'-GGCGGCACCACCATGTACCCT-3' } \\
\text { Reverse: 5'-AGGGGCCGGACTCGTCATACT-3' }\end{array}$ \\
\hline BCL2 & $\begin{array}{c}\text { Forward: 5'-TTGTGGCCTTCTTTGAGTTCGGTG-3' } \\
\text { Reverse: 5'-GGTGCCGGTTCAGGTACTCAGTCA-3' }\end{array}$ \\
\hline P53 & $\begin{array}{c}\text { Forward: 5'-TAACAGTTCCTGCATGGGCGGC 3' } \\
\text { Reverse: 5' 'AGGACAGGCACAAACACGCACC 3' }\end{array}$ \\
\hline BAX & $\begin{array}{c}\text { Forward: 5'-CCTGTGCACCAAGGTGCCGGAACT-3' } \\
\text { Reverse: 5'-CCACCCTGGTCTTGGATCCAGCCC-3' }\end{array}$ \\
\hline Ikab & $\begin{array}{c}\text { Forward: 5'-GATCCGCCAGGTGAAGGG-3' } \\
\text { Reverse: 5'-GCAATTCTGGCTGGTTGG-3' }\end{array}$ \\
\hline
\end{tabular}

Table 1

PRIMERS USED IN THIS STUDY 


\section{Lectin and cancer marker gene expressions}

Lectin anticancer activity profiling was tried, and its activity was examined on the expression of Bax, BCL-2 and IKab genes in the treated HepG2 cells. To this end, HepG2 cells were cultured in 12 well plates $\left(6 \times 10^{3}\right.$ cell/ $\mathrm{mL}$ ) for 2 days, with the recorded nontoxic concentration of lectin. After incubation, the cells were subjected to the RNA extraction and RT-q PCR, for quantification of the BAX, $B C L 2$ and IKab genes expression after and before treatment; the results were normalized using the beta actin as reference gene.

RNA extraction and CDNA synthesis and Quantitative PCR Treated and non-treated HepG2 cells were subjected to the RNA extraction, using RNA extraction kit (Qiagene, Germany), according to the manufacture procedures. First- strand CDNA was synthesized using oligo (dT) primer and the AMV reverse transcriptase (Promega Corp., Madison, WI); RT-PCR was performed using the SYBR Green PCR Master Mix (Fermentas, USA) [26]. Primers used in this study are presented in table 1 .

\section{Results and discussions}

In this study, cytotoxicity of the partial purified lectin of Pisum fulvum seeds was tested on the human noncancerous cells as fibroblast cells, Syrian hamster kidney cells (PHK) and Madin-Darby canine kidney cells (MDCK), using neutral red assay protocol (fig. 1). The obtained data revealed that beginning with the concentration $19.7 \mu \mathrm{g} /$ $\mathrm{mL}$ lectin, PHK cells were the most sensitive cells to the treatment, followed by the fibroblast cells, while MDCK
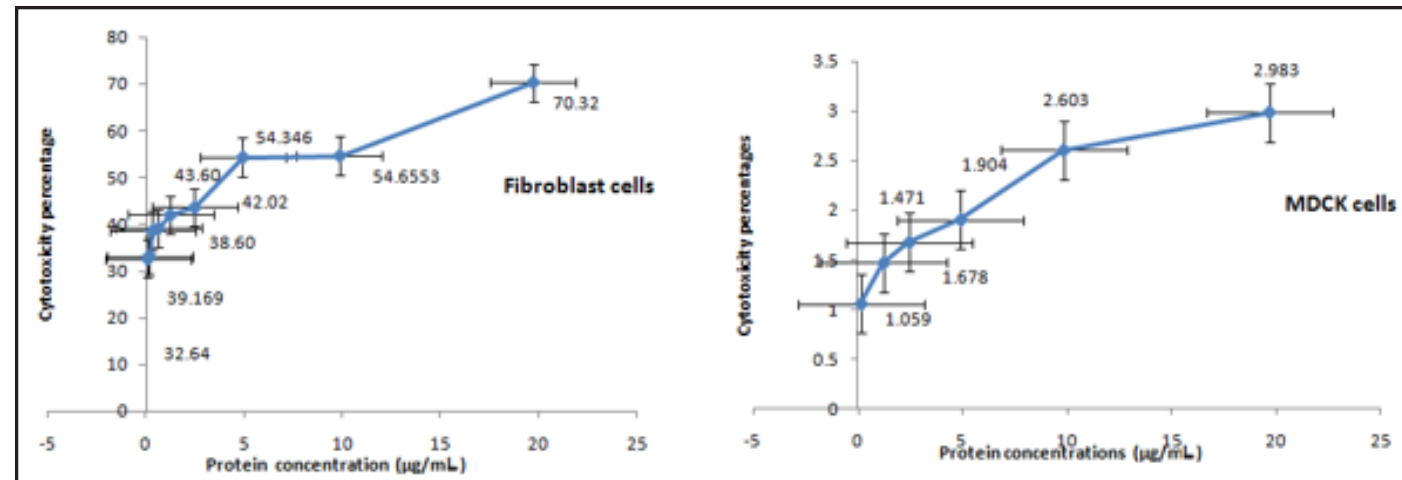

Fig. 1.The safety pattern of lectin on human fibroblast cells
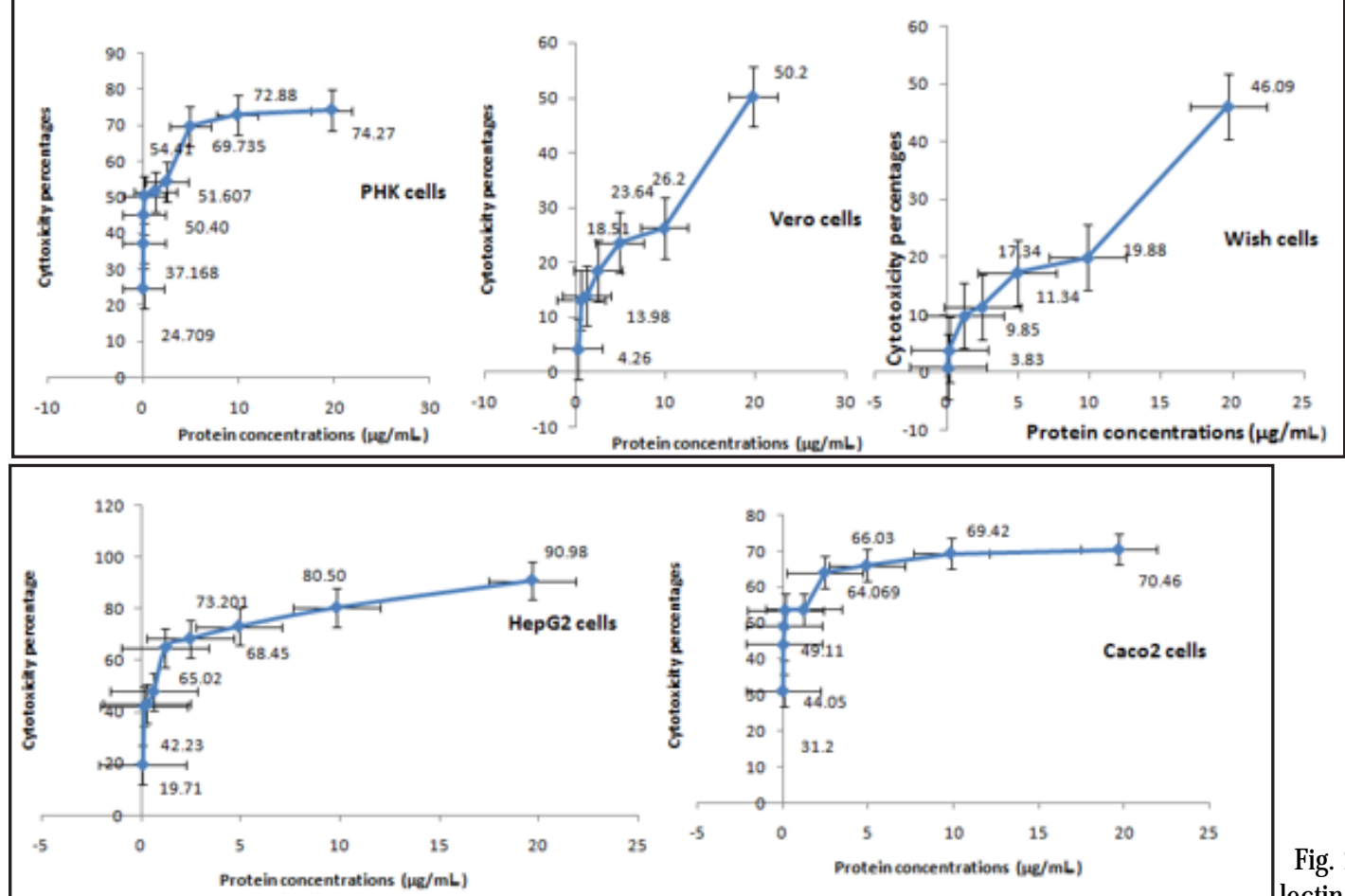

Fig. 2. Anticancer activity of lectin on HepG2, Caco2, Hep2 and MCF 7 cells
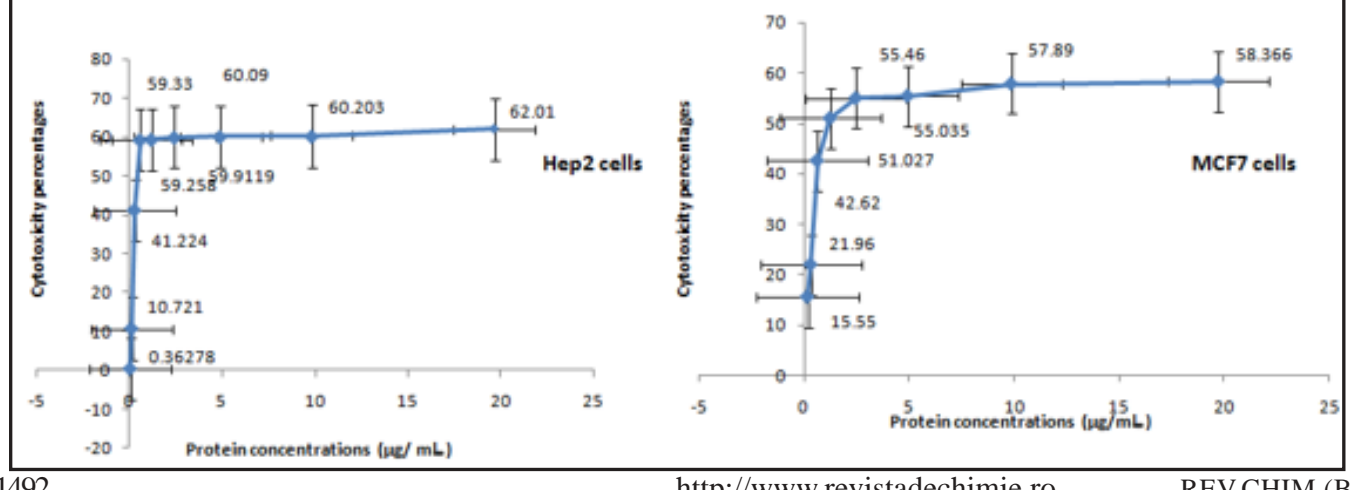
cells were the most tolerant cells to the treatment. Also, the kidney cells of the Green Monkey and the Human amnion cells recorded the moderate sensitivity percentages upon lectin treatment. In addition, IC50 of the extracted lectin on the noncancerous cells ranged from 19.7 to $2.4 \mu \mathrm{g}$ protein $/ \mathrm{mL}$.

The anticancer activities of the extracted lectin were checked against Caco2, Hep2, MCF7, and HepG2 cells. The concluded results indicated that the extracted lectin with the non-toxic dose was superior in its action against HepG2 cells, with an inhibition percentage varying from 68.45 to 90.98 , and a cancer cell selectivity index ranging from 3.5 to 28.14 (fig. 2).

On the other hand, MCF7 cells were the most resistant cells to the treatment, with the anticancer percentages ranging from 55.03 to 58.3. Also, Caco2 and Hep2 cells showed moderate responses to the treatment with the nontoxic dose of lectin, with inhibition percentages in cellular proliferations 64.06-70.46 and 59.91-62.02, respectively. At the end of HepG2 cells treatment, the morphological examinations of cells by inverted microscope indicated that HepG2 cells undergoing apoptosis are remarked by rounding up, shrinkage, membrane blabbing and loss of cell adhesion. It was observed that, the safe dose of wild lectin recorded $67.6 \%$ inhibition percentage in the thymidine analogue (known as 52 -bromo-22 -deoxyuridine or BrdU) hepatocellular carcinoma incorporation (fig. 3A, 3B).

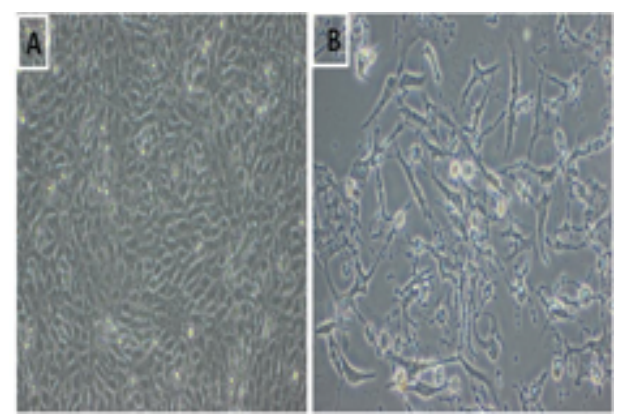

Fig. 3. Effect of the lectin dose on BrDU hepatocellular carcinoma: A - control cells, B - treated cells after $12 \mathrm{~h}$ with lectin dose

The antioxidants [27] are metabolites which prevent the oxidation of any oxidable substrates in the cells. The results that are presented in figure 4 showed the total antioxidant activities of the lectin in treated and non-treated HepG2 cells. The activity was scanned at wide wave length range and compared with 5FU as a standard anticancer drug. The obtained data indicated that the highest

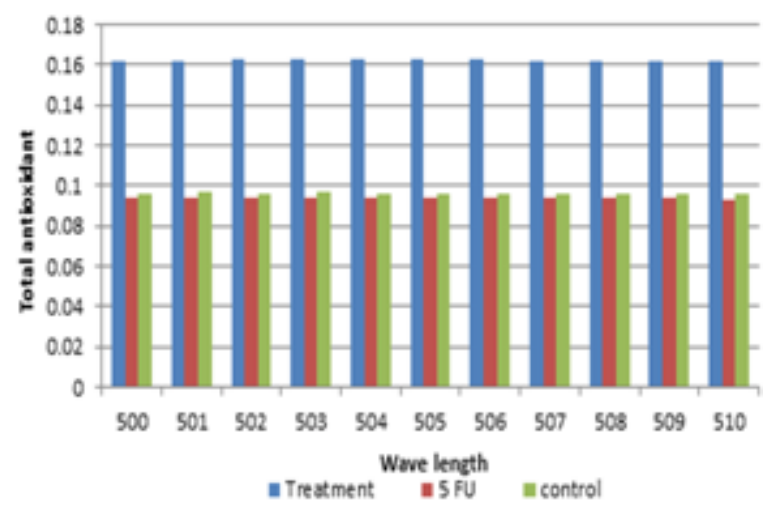

Fig. 4. The antioxidant activity of the Pisum lectin on the HepG2 cancer cell line

antioxidant activity was recorded in the lectin-treated cells case, followed by the negative control cells; the lowest antioxidant activity was observed with 5FU treated cells.

The ability of lectin to induce apoptosis was visualized by acridine orange/ethidium bromide fluorescent stains; lectin showed an ability to induce all stages of apoptosis (both early and late) by converting the nucleus appearance forming multinucleated cells, condensed nucleated cells, and chromatin fragmented cells, processes that were visualized under the fluorescent microscope (fig. 5A, 5B, and $5 \mathrm{C}$ ). Cells were impermeable to the ethidium bromide during early apoptotic stages and their nuclei stained green, but during late stages, this ability was lost, and the cell nuclei stained red, while inn the necrotic staged cells, cellular membrane permeability was disrupted. Cells became permeable to ethidium bromide that stained nucleus with a red stain, butwithoutnuclear condensation

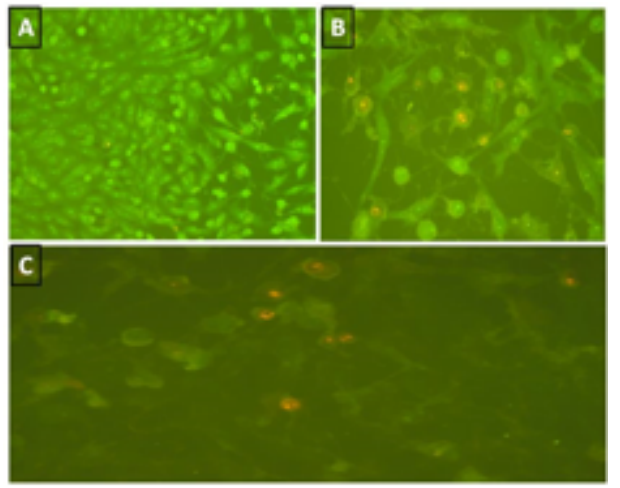

Fig. 5. Effect of the lectin on the cell apoptosis: A - control cells; B - treated cells in early stage of apoptosis; C - treated cells in late stage of apoptosis.

Table 2

GENE EXPRESSION IN TREATED HepG2 WITH LECTIN COMPARED WITH THE NON-TREATED CELLS

\begin{tabular}{|c|c|c|c|c|c|c|c|}
\hline Target & Sample & $\begin{array}{c}\text { Mean } \\
\mathrm{Cq}\end{array}$ & $\begin{array}{c}\text { Mean } \\
\text { Efficiency } \\
\text { Corrected Cq }\end{array}$ & $\begin{array}{c}\text { Normalized } \\
\text { Expression }\end{array}$ & $\begin{array}{c}\text { Relative } \\
\text { Normalized } \\
\text { Expression }\end{array}$ & $\begin{array}{c}\text { Regulation } \\
\text { Compared to } \\
\text { Regulation } \\
\text { Threshold }\end{array}$ \\
\hline Actin & $\mathrm{Ps}$ & 17.52 & 17.52 & - & - & - & No change \\
\hline Actin & ps control & 34.59 & 34.59 & - & - & - & No change \\
\hline Bax & $\mathrm{Ps}$ & 39.21 & 39.21 & 0.00000 & 0.00000 & -966131.94933 & Down reg. \\
\hline Bax & ps control & 36.39 & 36.39 & 0.28705 & 1.00000 & 1.00000 & No change \\
\hline Bcl2 & $\mathrm{Ps}$ & 27.01 & 27.01 & 0.00140 & 0.02026 & -49.35364 & Down reg. \\
\hline Bcl2 & ps control & 38.45 & 38.45 & 0.06898 & 1.00000 & 1.00000 & No change \\
\hline IKab & Ps & 2.76 & 2.76 & 27751.69098 & 42.28900 & 42.28900 & Up reg. \\
\hline IKab & ps control & 25.23 & 25.23 & 656.23899 & 1.00000 & 1.00000 & No change \\
\hline
\end{tabular}


they showed either normal nuclear structure or no nuclear staining.

At the end of HepG2 cells treatment with nontoxic dose of lectin and comparing with the controlled cells, the lectin showed potentialities to down regulate the expression of $\mathrm{BCL} 2$ and Bax genes and upregulate IKab genes that inhibit NF-кB inflammatory pathway (table 2). All obtained gene expression data were normalized with $\beta$ actin gene expression.

The current study was designed to reveal the safety pattern of Pisum fulvum lectin on different non-cancerous mammalian cells in vitro. Our obtained data indicated that cells were relatively resistant to the lectin treatment and among all treated cells, PHK and fibroblasts were the most sensitive cells to the treatment, while MDCK and WISH were the most tolerating cells. Few studies explained the cytotoxicity actions on cells in vitro; Pauly et al. measured the cytotoxicity effects of active ricin on MDCK cells using cell-electrode impedance measurement [28]. They reported that, after $24 \mathrm{hrs}$, the sensitive detection was determined with an IC50 of $0.4 \mathrm{ng} / \mathrm{mL}$. Kuramoto et al. suggested that MDCK cells showed the highest susceptibility to CEL-I lectin toxicity by causing plasma membrane disorder without induction of apoptosis, but no significant toxicity was recorded during lectin treatment with doses up to $10 \mathrm{microg} / \mathrm{mL}$ [29]. In that context, the amount of bound lectin on the sensitive cell lines was greater than that on the resistant cell lines [30], concluding that different susceptibility of the cell lines to lectin toxicity is partly explained by different binding efficiencies of the lectin types to these cell lines. This suggestion could explain why MDCK were the most tolerating cells to the lectin of $P$. sativum as toxicity depends on the lectin type. In contrast to our current result, Reis et al. evaluated the use of lectin extracted from Bauhinia variegata (BVL) at events of cytotoxicity in MDCK and fibroblastcells [31]. They reported that BVL with concentrations of $50-25 \mu \mathrm{g} / \mathrm{mL}$ stimulated the proliferation of MDCK and fibroblast cells, observing that BVL could be used as stimulating tissue healing agent. The all above mentioned findings and our obtained data that showed different sensitivity of the three different kidney cells used (PHK, MDCK, and VERO) to lectin treatment, supporting the idea of different susceptibility of cells to lectin toxicity which completely depends on the extracted lectin type. On the other hand, it is well known that lectins have the capacity to differentiate between normal and malignant cells [32]. It was reported that not all lectins are potent toxins and most toxic lectins kill the animal cells by impressive protein synthesis, by which specific cytotoxic chemotherapeutic agents were developed [32]. The plant protein ricin has emerged as the toxin of choice for such constructs.

In the last two decades, some plant lectins have been used to differentiate between malignant and benign tumours, and the degree of glycosylation was associated with the cancer metastasis [33]; recently, the plant lectins have been developed in sophisticated microarrays for a better understanding of the malignant tumours, for diagnosis and identification of the different cancer developmental stages. Our results confirmed this theory (cancer cell selectivity), as our extracted lectin showed HepG2 cancer cells selectivity index ranged from 3.5 to 28.14 , compared with the non-cancerous cells. Also, some plant lectins with legume lectin domains as concanavalin A (ConA), Polygonatum cyrtonema lectin (PCL) from the GNA family and ricin B family lectins as mistletoe (MLs), exhibit remarkable anti-tumour potentials via regulating both apoptosis and autophagic cell death [34]. The legume lectins among the seven known classes of lectin have received more attention in cancer treatment due to their significant anti-tumour properties compared to the other lectin families [35].

The interaction with altered glycosylation patterns in the malignant cell surfaces and the lectins resulted in apoptosis, cytotoxicity, and inhibition of tumour growth [36]. Moreover, lectins from different sources inhibit cancer cells growth with different manner based on their concentration [37]. As example, lectin extracted from the glossy black soybean (glycine max) inhibited the proliferation of both breast cancer MCF7 cells and hepatoma HepG2 cells [38]. Del Monte banana lectin showed activity as anti-proliferative agent against leukemia (L1210) and hepatoma (HepG2) cells [39]; the extra-long autumn purple bean extracted lectin showed abilities to induce the production of apoptotic bodies of hepatoma HepG2 cells [40].

Our obtained results confirmed the anticancer effects of the extracted lectins against Caco2, Hep2, MCF7 and HepG2 cells with the superiority of their action against HepG 2 cells (inhibition percentage ranged from 68.45 to 90.98). In the same context, as the BrdU is mutagen to target rapidly dividing cancer cells, it is used universally to birth-date dividing cells because it incorporates into DNA chains [41] and sustains normal function at least in the short term [42]. It was suggested that BrdU plays a role in induction of the premature senescence in a wide range types of cells [43]. In this study, lectin safe dose recorded inhibition percentage in BrdU hepatocellular carcinoma incorporation $67.6 \%$.

Many reports have indicated that plant lectins such as ConA, PCL and the MLs induce cancer cell death by apoptosis, that was confirmed by our current results of the fluorescent dual Ao/EB staining that indicated the abilities of the extracted lectin to induce apoptosis. Apoptosis occurs through two major pathways; extrinsic (triggered by Fas family death receptors), and the mitochondriadependent intrinsic pathway that resulted in the release of cytochrome $c$ as well as activates death signals under appropriate stimuli [44]. Our current research confirmed the idea that legume lectin could induce cancer cell apoptosis through an intrinsic pathway through BCL2 and NF-êB pathway. Numerous reports have demonstrated that ConA can induce apoptotic cell death via the mitochondrial pathway in both human melanoma $A 375$ cells and human hepatocellular carcinoma HepG2 cells [45]. Also, it was described that proteins stimulation resulted in inducing apoptosis such as BAX, Puma and inhibition of BCL2 [46]. ConA has been reported to up-regulate COX-2 and downregulate Akt expression via the IKK/ NF-jB-dependent pathway in U87 glioblastoma cells [47]. Accumulating evidence has revealed that legume lectins can induce cancer cell death in a Bcl-2/adenovirus E1B 19 kDainteracting protein 3(BNIP-3)-mediated manner [48]. After associating with a mannose moiety residing on the cell membrane glycoprotein, via clathrin-mediated endocytosis, lectin can be internalized to the mitochondria, initiating autophagic cell death [49]. Plant lectins that were extracted from Pisum fulvum can kill many types of cancer cells by targeting apoptotic cell death involving many key signalling pathways.

\section{Conclusions}

With biochemical and molecular complexities of apoptotic pathways becoming better understood, new therapeutic strategies will be developed and these, in turn, will initiate other therapeutic strategies. Together, these 
findings provide a comprehensive perspective for further elucidating roles of plant lectins that may help them target apoptotic cell death pathways as potential agents in cancer pathogenesis and therapeutics especially hepatocellular carcinoma.

Acknowledgments: Authors thank the Professor Ibrahim Abd El-Rahim Mashaly, Botany Department, Faculty of Science, Mansoura University who identified the plant taxonomy.

\section{References}

1.SHARON, N., LIS, H., Glycobiol., 14, nr. 11, 2008, p. 53R.

2.VAN DAMME, E.J.M., LANNOO, N., PEUMANS, W.J ., Adv. Bot. Res., 48, 2008, p. 107.

3.THAKUR, A., RANA, M., LAKHANPAL T.N., AHMAD, A., KHAN M.I., Biochim. Biophys. Acta, 1770, nr. 9, 2007, p. 1404.

4.ISLAM, F., GOPALAN, V., LAM, A.K., KABIR, S.R., Int. J. Biol. Macromol, 117, 2018, p. 1050.

5.SUBRAMANYAM, S., SMITH, D.F., CLEMENS, J.C., WEBB, M.A., SARDESAI, N., WILLIAMS, C.E., Plant Physiol., 147, nr. 3, 2008, p. 1412. 6.NAEEM, A., HAQUE, S., KHAN, R.H. Protein J., 26, 2007, p. 403. 7.GUJA, C., BOTNARIU, G., CERGHIZAN, A., DINCA, M., POPA, A., SUCIU, G., Diab. Res. Clin. Pract., 120, nr. Suppl. 1, 2016, p. S101. 8.MOTA, M., POPA, S.G., MOTA, E., MITREA, A., CATRINOIU, D., CHETA, D.M., GUJA, C., HANCU, N., IONESCU-TIRGOVISTE, C., LICHIARDOPOL, R., MIHAI, B.M., POPA, A.R., ZETU, C., BALA, C.G., ROMAN, G., SERAFINCEANU, C., SERBAN, V., TIMAR, R., VERESIU, I.A., VLAD, A.R., J. Diabetes, 8, nr. 3, 2016, p. 336. DOI: 10.1111/1753-0407.12297 9.POPA, S., MOTA, M., POPA, A., MOTA, E., SERAFINCEANU, C., GUJA, C., CATRINOIU, D., HANCU, N., LICHIARDOPOL, R., BALA, C., ROMAN, G., RADULIAN, G., TIMAR, R., MIHAI, B., J. Endocrinol. Invest., 39, nr. 9, 2016, p. 1045. DOI: 10.1007/s40618-016-0470-4

10.GUJA, C., BOTNARIU, G., CERGHIZAN, A., DINCA, M., POPA, A., SUCIU, G., Diabetes mellitus as cardiovascular disease. International Conference on Interdisciplinary Management of Diabetes Mellitus and its Complications, 2016, p. 255. $2^{\text {nd }}$ International Conference on Interdisciplinary Management of Diabetes Mellitus and its Complications, INTERDIAB, Bucharest, Romania.

11.TSIVILEVA, O.M., NIKITINA, V.E., LOSHCHININA, E.A., Biochem., 73, nr. 10, 2008, p. 1154.

12.VASTA, G.R., AHMED, H., ODOM, E.W., Curr. Opin. Struct. Biol., 14, nr. 5, 2004, p. 617.

13.LANNOO, N., VAN DAMME, E.J ., Biochem. Biophys. Acta, 1800, nr. 2, 2010, p. 190.

14.GABIUS, H.J., ANDRE, S., KALTNER, H., SIEBERT, H.C., Biochim. Biophys. Acta, 1572, nr. 2-3), 2002, p. 165.

15.ROMAN, G., BALA, C., CRETEANU, G., GRAUR, M., MOROSANU, M., AMORIN, P., PIRCALABOIU, L., RADULIAN, G., TIMAR, R., CADARIU, AA. Acta Endocrinol.-Bucharest., 11, nr. 1, 2015, p. 64. DOI: 10.4183/ aeb. 2015.64

16.GUJA, C., IOACARA, S., CATRINOIU, D., NEGRISANU, G., POPA, A. Interdisciplinary Approaches in Diabetic Chronic Kidney Disease, 2015, p. 230. $1^{\text {st }}$ International Conference on Interdisciplinary Management of Diabetes Mellitus and its Complications, INTERDIAB, Bucharest, Romania.

17.HUSSEIN, S., POPA, A.R., ALBU, M.S., Diabetologia, 44, nr. Supplement 1, 2001, p. A138

18.RIBEIRO, A.C., FERREIRA, R., FREITAS, R., Plant Lectins: Bioactivities and Bioapplications. In Rahman A, Edt. Studies in Natural Products Chemistry, Elsevier, 2018, p. 1-42.

19.SINGH, P., ZIMMERLI, L., Front Plant Sci; 4, 2013, p. 124. https:// doi.org/10.3389/fpls.2013.00124.

20.NISHIMURA, R., HAYASHI, M., WU, G.-J ., KOUCHI, H., IMAIZUMIANRAKU, H., MURAKAMI, Y., KAWASAKI, S., AKAO, S., OHMORI, M., NAGASAWA, M., HARADA, K., KAWAGUCHI, M., Nature, 420, 2004, p. 426. https://doi.org/10.1038/nature01231
21.AL-SOHAIMY, A., HAFEZ, E.E., ABDELWAHAB, A.E., EL-SAADANI, M.A., Aust. J. Basic Appl. Sci., 1, nr. 3, 2007, p. 213.

22.CAGLIARI, R., KREMER, F.S., DA SILVA PINTO, L., Int. J. Biol. Macromol, 119, 2018, p. 811. https://doi.org/10.1016/j.ijbiomac. 2018.07.156

23.SINGH, M., UPADHYAYA, H.D., BISHT, I.S., Introduction. In: Singh M, Upadhyaya HD, Bisht IS, Edts. Genetic and Genomic Resources of Grain Legume Improvement, Elsevier, 2013, p. 1-10.

24.BORENFREUND, E., PUERNER, J.A., J. Tissue Cult. Meth., 9, nr. 1, 1985, p. 7.

25.YASSIN, A.M., ELNOUBY, M., EL-DEEB, N.M., HAFEZ, E.E., Appl. Biochem. Biotechnol., 180, nr. 4, 2016, p. 623. https://doi.org/10.1007/ s12010-016-2120-x

26.COLIGAN, J .E., KRUISBEEK, A.M., MARGULIS, D.H., SHEVACH, E.M., STROBER, W., Edts. Current Protocols in Immunology, Wiley Ed., New York, 1995.

27.FODOR, K., TIT, D.M., PASCA, B., BUSTEA, C., UIVAROSAN, D., ENDRES, L., IOVAN, C., ABDEL-DAIM, M., BUNGAU, S., Oxid. Med. Cell. Longev., 2018, ID 4147320, 2018. https://doi.org/10.1155/2018/ 4147320

28.PAULY, D., WORBS, S., KIRCHNER, S., SHATOHINA, O., DORNER, M.B., DORNER, B.G., PLoS one, 7, nr. 4, 2012, p. e35360.

29.KURAMOTO, T., UZUYAMA, H., HATAKEYAMA, H., TAMURA, T., NAKASHIMA, T., YAMAGUCHI, K., ODA, T., J. Biochem., 137, nr. 1, 2005, p. 41.

30.REIS, L., RIZZI, C., MONTE, L., LABONDE, J., HARTLEBEN, C., CONCEICAO, F., PINTO, L., BMC Proceedings, 8, 2014, P265. https:// doi.org/10.1186/1753-6561-8-S4-P265

31.SABOVA, L., PILATOVA, M., SZILAGYI, M., SABO, R., MOJ ZIS, R., Phytother. Res., 24, 2010, p. 365. https://doi.org/10.1002/ptr.2947

32.LORD, J.M., Plant, Physiol., 85, nr. 1, 187, p. 1.

33.MODY, R., JOSHI, S., CHANEY, W., J. Pharmacol. Toxicol. Meth., 33, 1995, p. 1.

34.ZHANG, X., CHEN, L.X., OUYANG, L, CHENG, Y., LIU, B., Cell Prolif., 45, nr. 5, 2012, p. 466. https://doi.org/10.1111/j.1365-2184.2012.00833.x 35.FAHEINA-MARTINS, G.V., DA SILVEIRA, A.L., CAVALCANTI, B.C., RAMOS, M.V., MORAES, M.O., PESSOA, C., ARAUJO, D.A.M., Toxicol. Vitro, 26, nr. 7, 2012, p. 1161. https://doi.org/10.1016/j.tiv.2012.06.017 36.ABDULLAEV, F.I., GONZALEZ DE MEJ IA, E., Arch. Latinoam. Nutr., 47, nr. 3, 1997, p. 195.

37.PRYME, I.F., BARDOCZ, S., Eur. J. Gastroenterol. Hepatol., 13, nr. 9, 2001, p. 1041.

38.LIN, P., YE, X., NG, T., Acta Biochim. Biophys. Sin. (Shanghai), 40, 2008, p. 1029.

39.CHEUNG, A.H., WONG, J.H., NG, T.B., Phytomed, 16, nr. 6-7, 2009, p. 594. https://doi.org/10.1016/j.phymed.2008.12.016

40.FANG, E.F., LIN, P., WONG, J.H., TSAO, S.W., NG, T.B., J Agric Food Chem., 58, 2010, p. 2221. https://doi.org/10.1021/j9903964u

41.LITTLEFIELD, J.W., GOULD, E.A., J. Biol. Chem., 235, 1959, p. 1129.

42.LIU, J.J ., LIN, M., YU, J.Y., LIU, B., BAO, J.K., Cancer Lett. 300, nr. 2, 2011, p. 105. https://doi.org/10.1016/j.canlet.2010.10.001

43.MICHISHITA, E., NAKABAYASHI, K., SUZUKI, T., KAUL, S.C., OGINO, H., FUJ II, M., MITSUI, Y., AYUSAWA, D., J. Biochem., 126, 1999, p. 1052. 44.LIU, B., LI., C.Y., BIAN, H.J ., MIN, M.W., CHEN, L.F., BAO, J.K., Arch. Biochem. Biophys., 482, nr. 1-2, 2009, p. 1. https://doi.org/10.1016/ j.abb.2008.12.003

45.WANG, Y., NANGIA-MAKKER, P., BALAN, V., HOGAN, V., RAZ, A., Cell Death Dis., 1, 2010, p. 101. https://doi.org/10.1038/cddis.2010.79 46.SINA, A., PROULX-BONNEAU, S., ROY, A., POLIQUIN, L., CAO, J., ANNABI, B., J. Cell Commun. Signal, 4, nr. 1, 2010, p. 31.

47.CHANG, C.P., YANG, M.C., LIU, H.S., LIN, Y.S., LEI, H.Y., Hepatology, 45, nr. 2, 2007, p. 286. https://doi.org/10.1002/hep.21509

48.LEI, H.Y., CHANG, C.P., J. Biomed. Sci., 16, nr. 1, 2009, p. 10. 49.HAFEZ, E.E., EL-DEEB, N., EL REFAEY, H., BOTROS, W., Asian Academic Res. J. Multidisciplinary, 2, nr. 3, 2015, p. 28.

$\overline{\text { Manuscript received: } 6.10 .2018}$ 